\title{
Spatial dimension of nigral astrogliosis observed in rotenone model of Parkinson's disease
}

\author{
A.O. Bogdaniuk, A.G. Nikonenko \\ Bogomoletz Institute of Physiology, National Academy of Sciences of Ukraine, Kyiv; \\ e-mail:agn@biph.kiev.ua
}

\begin{abstract}
This paper addresses spatial aspects of reactive astrogliosis observed in the substantia nigra pars compacta $(\mathrm{SNc})$ in rotenone model of Parkinson's disease. The study was performed on adult male Wistar rats receiving the intracerebral $12 \mu \mathrm{g}$ rotenone infusion into the left SNc. SNc tissue was analyzed 40, 70 and 200 days after the infusion. It was shown that rotenone caused the increase in astocyte density at all analyzed time-points, thus indicating the proliferation of the cells. Radial distribution function (RDF) analysis demonstrated a non-uniform spatial distribution of nigral astrocytes. Their density was revealed to be higher in the proximity of neuronal cell bodies, especially on the infused side. In addition, RDF analysis provided evidence of spatial clusters of astrocytes 40 days after the infusion. The results of this study suggest that nigral astrogliosis observed in the rotenone model of Parkinson's disease includes changes in spatial distribution of astrocytes. These changes reflect the rearrangement of $S N c$ tissue architecture occurring in response to rotenone-related degeneration of SNc neurons.
\end{abstract}

Key words: animal model; astrocytes; Parkinson's disease; rotenone; spatial pattern.

\section{INTRODUCTION}

Astrocytes are star-shaped glial cells that serve a number of vital roles in the brain tissue. They provide biochemical support for endothelial cells to form the blood-brain barrier, assist in maintaining ion balance, actively participate in the regulation of local blood flow [1,2]. Astrocytic processes ensheathing synapses limit the diffusion of neurotransmitters [3] and express proteins capable to influence synaptic activity [4]. In addition, astrocytes express receptors for various neurotransmitters. The activation of these receptors leads to oscillations in intracellular $\mathrm{Ca}^{2+}$ levels [5].

Astrocytes respond to brain tissue impairments by undergoing a transformation commonly referred to as reactive astrogliosis. The intensity of reactive astrogliosis is variable and depends on the severity of a CNS insult. Astrocytes are involved in the complex regulation of inflammation in the central nervous system (CNS). Important roles that astrocytes play in the brain tissue entail their specific (C) A.O. Bogdaniuk, A.G. Nikonenko spatial arrangement. Their cell bodies are evenly distributed in the tissue and astrocytic processes overlap only minimally, such that each astrocyte covers an exclusive territory of neuropil [6]. Thus, astrocytes contribute to some extent to the brain tissue architecture by creating microanatomical domains, which size is defined by the length of their processes [7]. Individual astrocytes are parts of a sinthitium, i.e. they are connected together with gap junctions.

Changes in the spatial arrangement of astrocytes may be an indicator of a brain tissue insult. Because spatial aspects of astrogliosis remain poorly understood, our aim was to analyze the spatial relationship between neuronal and astrocytic populations in substantia nigra pars compacta ( $\mathrm{SNc}$ ) area in the rotenone model of Parkinson's disease.

\section{METHODS}

Spatial patterns formed by nigral astrocytes were analyzed in adult male Wistar rats (250-300 g) infused intracerebrally with $12 \mu \mathrm{g}$ of rotenone 
("Sigma", USA) in $1 \mu 1$ dimethyl sulfoxide, into the left SNc. The details of the infusion procedure were described earlier [8]. Five animals per each experimental group were studied, 25 rats in total. Animals were anesthetized, and transcardially perfused with $4 \%$ formaldehyde and $2.5 \%$ glutaraldehyde in $0.1 \mathrm{M}$ phosphate buffer ( $\mathrm{pH} 7.4) 40,70$ or 200 days after the rotenone infusion.

Their brains were removed and cut into 200- $\mu \mathrm{m}$-thick transverse slices, which were kept in the same fixative for 1.5 hours, and postfixed in $1 \% \mathrm{OsO}_{4}$. Tissue slices were then dehydrated in an ascending series of ethanol followed by dry acetone and embedded in Epon resin (Epon 812, "Sigma", USA). Semithin 1- $\mu$ m-thick sections were made using ultramicrotome ("LKB", Sweden) and stained with $1 \%$ solution of toluidine blue. Microphotos of SNc tissue on the infused side and respective contralateral side (control area) were made using XSP-13a microscope
("Nanbei", China) equipped with digital camera at $40 \times$ objective magnification. In addition, microphotos of SNc tissue of intact and shamoperated (infused with dimethyl sulfoxide only) animals were taken.

Astrocyte density (AD) was quantified by counting the number of astrocytes for each sample area of $372.8 \mu^{2}$ (at the level of the tissue) and expressed as cells/10000 $\mu^{2}$. Radial distribution function (RDF) was used to quantify spatial patterns formed by astrocytes. In this particular case, RDF described the density of astrocytes occurring at the distance $r$ and $r+\Delta r$ from a reference object. The analyzed range of distances was limited to $100 \mu \mathrm{m}$ and divided into five $20-\mu \mathrm{m}$-wide intervals. As all directions from a reference object were explored, aforementioned sampling intervals may be presented as concentric circular regions. Second-fifth regions are, in fact, circular rings or annuli (Fig. 1). Astrocyte

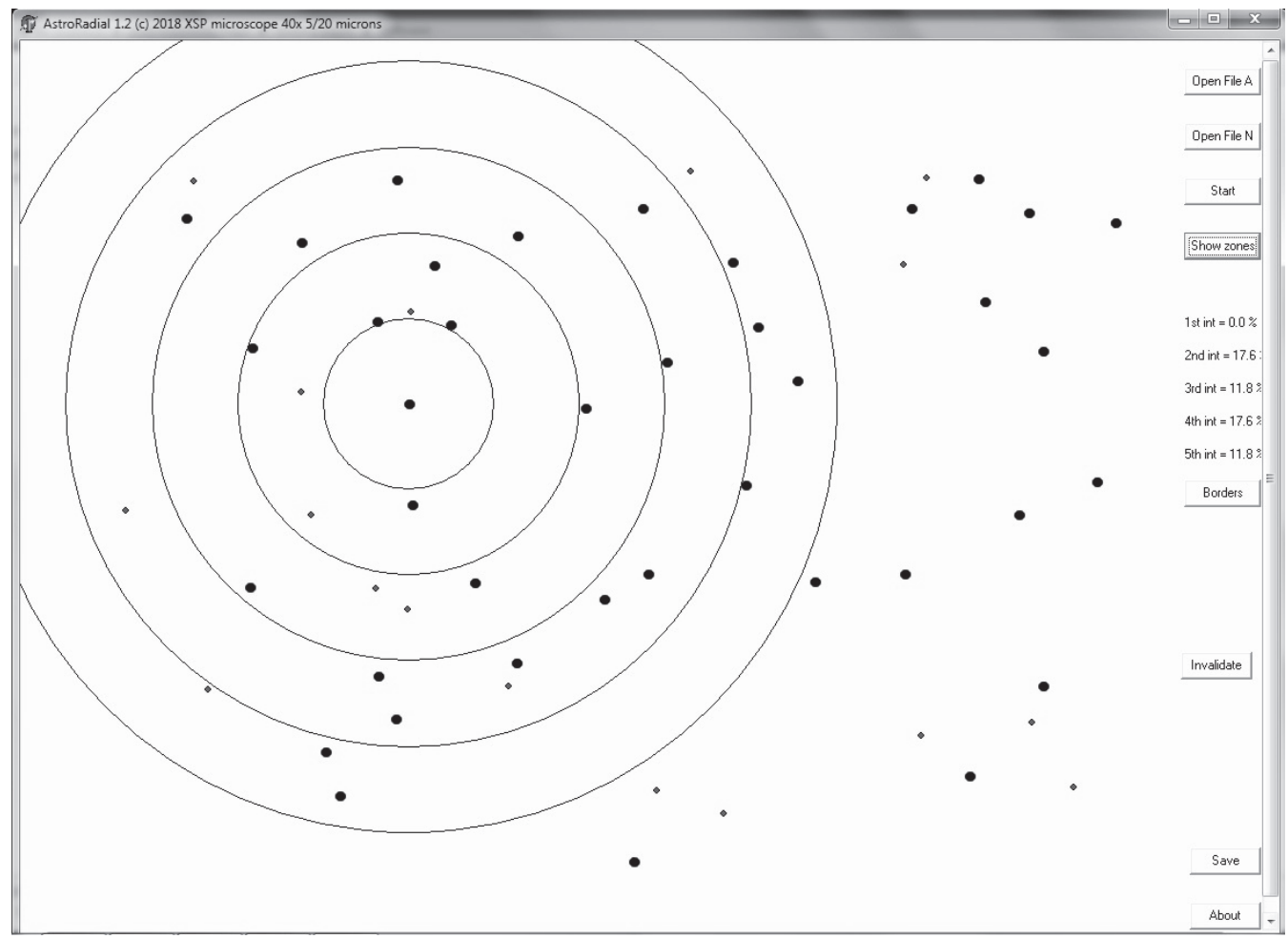

Fig. 1. A screenshot of the software interface displaying neuronal profile centroids (large dots), astrocyte profile centroids (small dots) and five RDF sampling regions for a given reference neuron 
counts were normalized to the area of a sampling region and expressed as AD. Spatial clustering of astrocytes was also quantified using RDF analysis but sampling only the first region (a circle with a radius $=20 \mu \mathrm{m})$. A custom-made software written in Delphi (Version 7, Borland Software Corporation, Scotts Valley, CA) to run a RDF algorithm uses coordinates of cell profile centroids as an input.

The coordinates were measured with an "ImageJ" open source software (Version 1.51j8, National Institutes of Health, USA) in digital micrographs. In total, 3083 astrocytes and 3466 neurons were analyzed. Individual values were pooled per experimental group. Statistical analysis was performed using Statistica software (v. 5, StatSoft, Tulsa, OK). Values are shown as mean \pm standard error of the mean. The nonparametric two-tailed Kolmogorov-Smirnov test was used to assess the differences between samples. $\mathrm{P}<$ 0.05 was considered statistically significant.

\section{RESULTS}

Visual inspection of SNc tissue micrographs revealed groups of medium-sized, multipolar neurons scattered in neuropil. The neuropil was tight, lacking any significant interstitial spaces. On the infused side, some neurons displayed a mild degree of degeneration including pyknosis and shrinking of the nucleus. Occasionally, glial cells were observed in the SNc tissue. Astrocytes were easily identified by their characteristic round nuclei (Fig. 2).

We used AD parameter to quantify the effects of rotenone. Its infusion led to more than $30 \%$ increase in $\mathrm{AD}$ value, up to $3.49 \pm 0.13$ cells / $10000 \mu \mathrm{m}^{2}(\mathrm{n}=35)$ with respect to the control value, $2.60 \pm 0.12$ cells / $10000 \mu^{2}(\mathrm{n}=27)$ on the contralateral side $(\mathrm{P}<0.01$; Fig. 3$)$. It is worth to note that $\mathrm{AD}$ was equal to $2.56 \pm 0.14$ cells / $10000 \mu^{2}(n=23)$ in the SNc tissue of intact control animals, while amounting to $2.73 \pm 0.16$ cells / $10000 \mu \mathrm{m}^{2}(\mathrm{n}=21)$ in the tissue of sham-operated control animals $(\mathrm{P}>0.05$ in both cases).

70 days after the infusion $\mathrm{AD}$ equalled $3.45 \pm 0.16$ cells $/ 10000 \mu \mathrm{m}^{2}(\mathrm{n}=34)$ on the infused side versus the control value of $2.58 \pm 0.14$ cells $/$ $10000 \mu \mathrm{m}^{2}(\mathrm{n}=25)(\mathrm{P}<0.01) .200$ days after the rotenone infusion $\mathrm{AD}$ was equal to $3.60 \pm 0.12$ cells / $10000 \mu^{2}(n=40)$ on the infused side differing significantly from the value for the noninfused side, $2.63 \pm 0.11$ cells $/ 10000 \mu \mathrm{m}^{2}(\mathrm{n}=35)$ $(\mathrm{P}<0.01)$. These data indicate that the increase in $\mathrm{AD}$ takes place within first 40 days after the rotenone infusion and the value of the parameter does not essentially change afterwards.

In order to detail rotenone-related AD changes in SNc tissue we applied RDF analysis. The

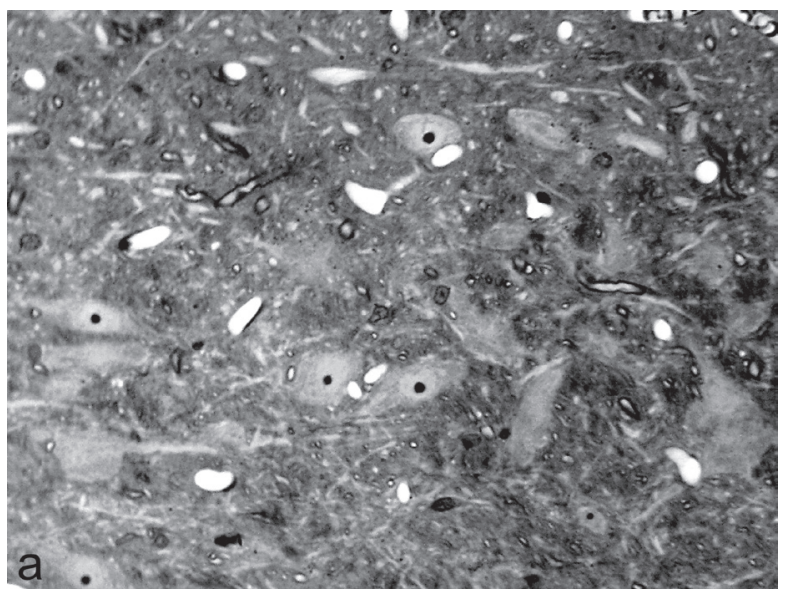

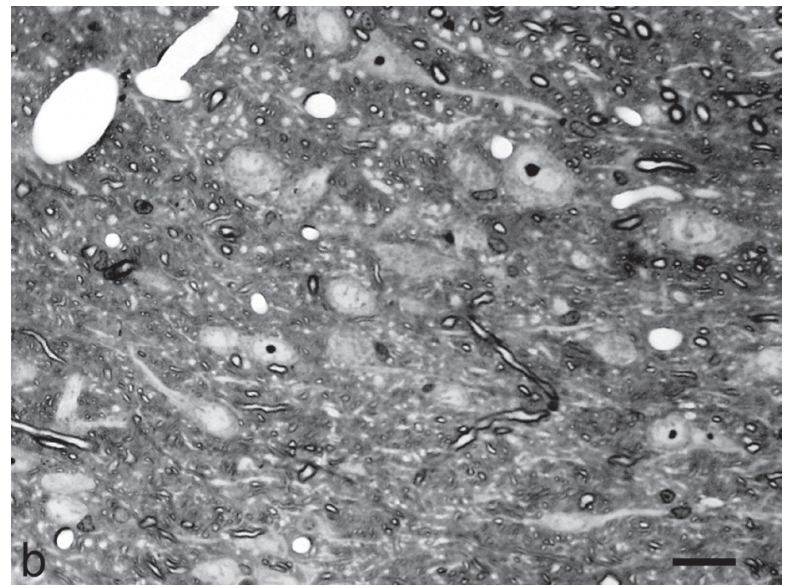

Fig. 2. Representative micrographs illustrating the SNc tissue 200 days after the $12 \mu \mathrm{g}$ rotenone infusion, on the infused side (a) and contra-lateral (control) side (b). Scale bar $=20 \mu \mathrm{m}$ 


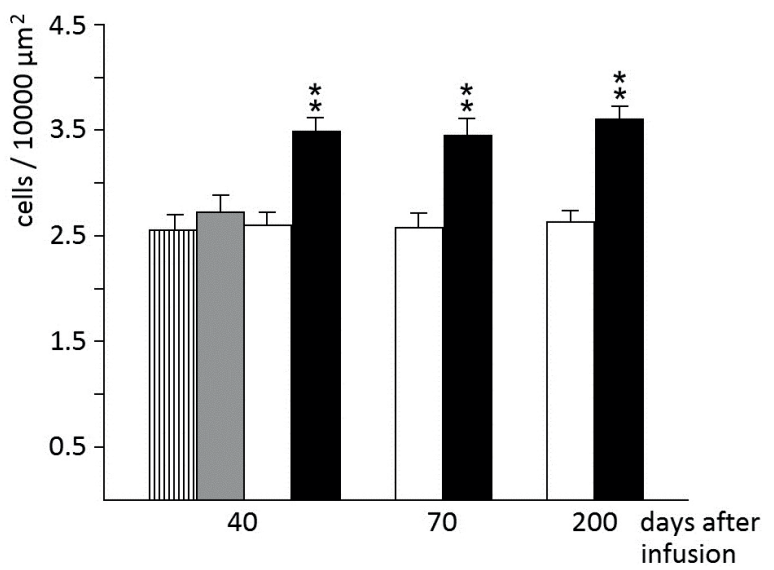

Fig. 3. Astrocyte density in the SNc tissue at different timepoints after the $12 \mu \mathrm{g}$ rotenone infusion, on the infused side (filled black bars) and contralateral side (open bars) (** $\mathrm{P}<0.01)$, as well as in the SNc tissue of intact (stripped bar) and sham-operated (filled gray bar) controls

most pronounced changes were observed in the first two RDF sampling intervals (Fig. 4a-c). In the group of animals analyzed 40 days after the rotenone infusion, AD in the first interval was equal to $4.27 \pm 0.26$ cells / $10000 \mu \mathrm{m}^{2}(\mathrm{n}=479)$ on the infused side, and $2.68 \pm 0.19$ cells / 10000 $\mu \mathrm{m}^{2}(\mathrm{n}=678)$ on the contralateral side. The difference between experimental and control regions amounted to $59.3 \%$ being statistically significant $(\mathrm{P}<0.01$; Fig. $4 \mathrm{a})$. In the second RDF interval, AD equalled $3.34 \pm 0.15$ cells / $10000 \mu^{2}(n=479)$, that was $43.3 \%$ larger of the control value, $2.33 \pm 0.10$ cells / $10000 \mu \mathrm{m}^{2}$ $(\mathrm{n}=678)(\mathrm{P}<0.01)$.

70 days after the infusion, $A D$ value in the first RDF sampling interval was equal to $3.37 \pm 0.21$ cells / $10000 \mu^{2}(n=729)$ on the infused side being $44.6 \%$ higher of the respective control value, $2.33 \pm 0.16$ cells $/ 10000 \mu \mathrm{m}^{2}$ $(n=564)(P<0.05$; Fig. 4b). In the second RDF interval $\mathrm{AD}$ equalled $3.00 \pm 0.11$ cells / 10000 $\mu^{2}(n=729)$ being $40.8 \%$ larger of the control value, $2.13 \pm 0.09$ cells / $10000 \mu^{2}(n=564)$ $(\mathrm{P}<0.01)$.

In the group of animals analyzed 200 days after the rotenone infusion, AD value in the first RDF sampling interval amounted to $3.29 \pm 0.24$ cells / $10000 \mu \mathrm{m}^{2}(\mathrm{n}=597)$ on the infused side and $2.24 \pm 0.20$ cells / $10000 \mu \mathrm{m}^{2}(\mathrm{n}=465)$ on the contralateral side. This $46.9 \%$ difference was statistically valid ( $\mathrm{P}<0.05$; Fig. $4 \mathrm{c})$. In the second RDF interval, AD was equal to $3.08 \pm 0.13$ cells / $10000 \mu^{2}(n=597)$ being $32.2 \%$ larger of the control value, $2.33 \pm 0.12$ cells / $10000 \mu \mathrm{m}^{2}$ $(\mathrm{n}=465)(\mathrm{P}<0.01)$.
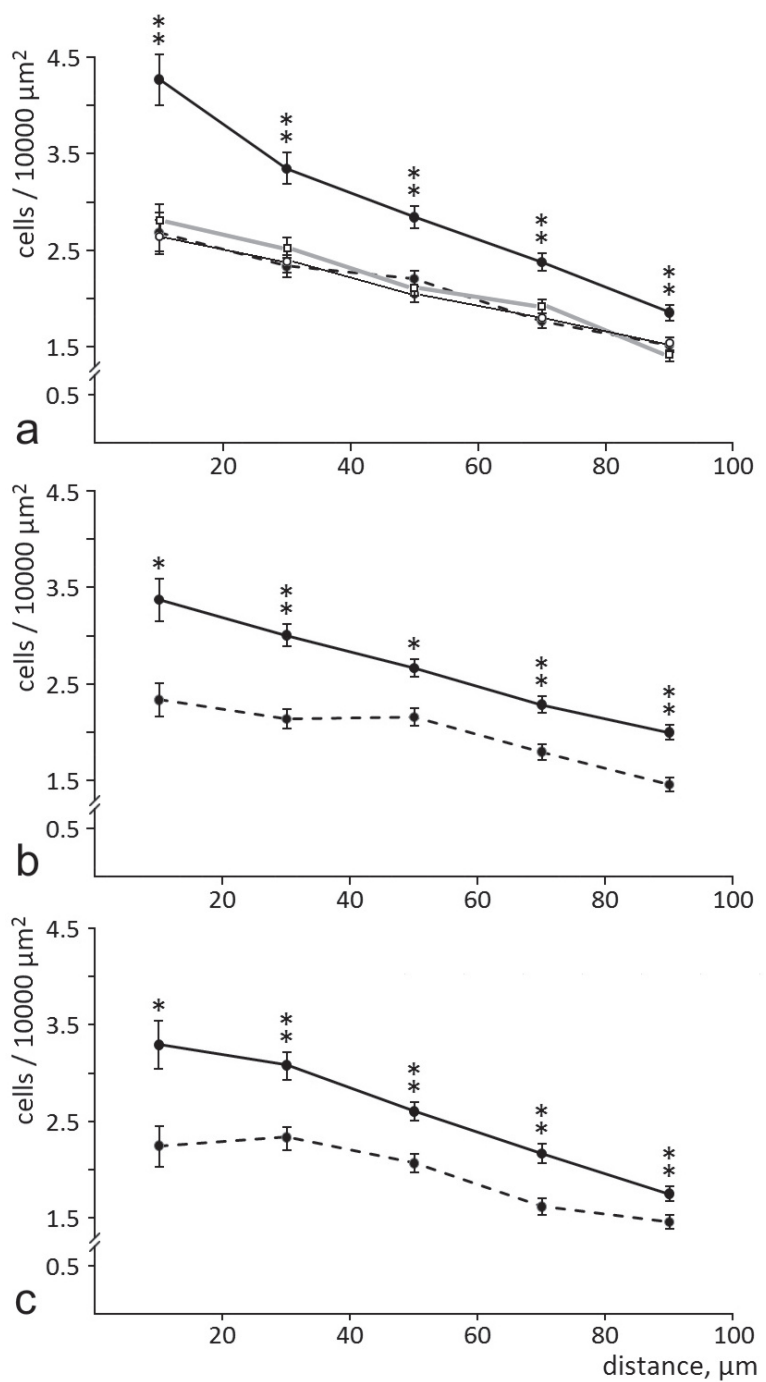

Fig. 4. Astrocyte density as a function of distance from the centroid of a neuronal profile in the SNc tissue 40 (a), 70 (b) and 200 (c) days after the $12 \mu \mathrm{g}$ rotenone infusion, on the infused side (black circles, continuous line) and contralateral (control) side (black circles, dashed line), as well as in the SNc tissue of intact (open circles, continuous line) and sham-operated (open squares, gray line) controls $\left({ }^{*} \mathrm{P}<0.05 ; * * \mathrm{P}<0.01\right)$ 
Together, these data reveal that at any timepoint analyzed the probability of an astrocyte to occur within the investigated range of distances from neurons $(0-100 \mu \mathrm{m})$ was higher on the infused side than on the contralateral one. The most striking differences were observed in the first two intervals of the analyzed range, for which $r$ was equal to 20 and $40 \mu \mathrm{m}$. AD tends to decrease in the first two RDF sampling intervals with time after the infusion. Our interpretation of this result is that it is because of a partial loss of neurons.

In order to analyze spatial clustering of astrocytes, we applied RDF analysis with minor modifications. This time, an astrocyte cell body not a neuronal one, was used as a reference object and only the first RDF interval was investigated. A pronounced clustering of astrocytes was revealed 40 days but not 70 or 200 days after the rotenone infusion (Fig. 5). At this timepoint, AD was equal to $4.07 \pm 0.03$ cells / 10000 $\mu^{2}(\mathrm{n}=537)$ on the infused side versus the value for the contralateral side, $2.89 \pm 0.03$ cells $/ 10000 \mu \mathrm{m}^{2}(\mathrm{n}=308)(\mathrm{P}<0.01)$. AD amounted to $3.02 \pm 0.05$ cells $/ 10000 \mu \mathrm{m}^{2}(\mathrm{n}=405)$ in the SNc tissue of intact control animals, while equalling $2.97 \pm 0.04$ cells $/ 10000 \mu \mathrm{m}^{2}(\mathrm{n}=392)$ in the tis-

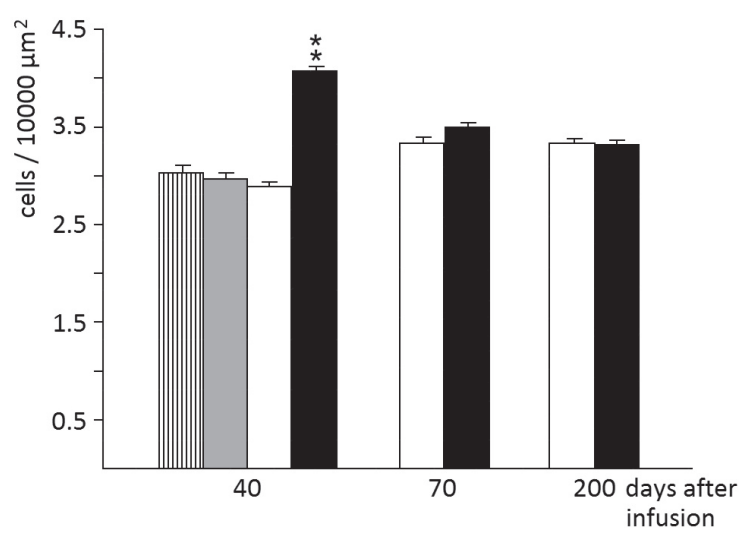

Fig. 5. Astrocyte density within $20 \mu \mathrm{m}$ distance from the centroid of an astocyte profile in the SNc tissue at different time-points after the $12 \mu \mathrm{g}$ rotenone infusion, on the infused side (filled black bars) and contralateral side (open bars), as well as in the SNc tissue of intact (stripped bar) and shamoperated (filled gray bar) controls $(* * \mathrm{P}<0.01)$ sue of sham-operated control animals $(\mathrm{P}>0.05$ in both cases).

70 days after the rotenone infusion $\mathrm{AD}$ made up $3.50 \pm 0.03$ cells / $10000 \mu^{2}(n=514)$ with respect to the control value, $3.33 \pm 0.04$ cells / $10000 \mu \mathrm{m}^{2}(\mathrm{n}=282)(\mathrm{P}>0.05) .200$ days after the infusion $\mathrm{AD}$ was equal to $3.32 \pm 0.03$ cells / $10000 \mu \mathrm{m}^{2}(\mathrm{n}=624)$ versus the control value, $3.33 \pm 0.03$ cells $/ 10000 \mu \mathrm{m}^{2}(\mathrm{n}=402)(\mathrm{P}>0.05)$.

These findings demonstrate quantitatively that spatial changes in nigral astrocytic population that occur in response to the intracerebral infusion of rotenone include transient clustering and migration of astrocytes towards degenerating neurons.

\section{DISCUSSION}

Astrocytes amount to approximately $30 \%$ of the total number of cells in mammalian brains, with considerable variability between brain regions. They are sparse in areas with a high density of neuronal cell bodies, whereas they are replete in areas with dendrites and axons [1]. Astrocytes function as a syncytium and have regional distinctions in functional properties. These cells are thought to be specialized for interactions with their own particular neuronal neighbors.

Localization of astrocytes within clearly defined regions is a phenomenon generally typical of CNS [9]. Astroglial cells may act as stable repositories of spatial information necessary for the development and local regulation of brain function. Localization of astrocytes is determined in embryonal period and does not change during postnatal life [7]. Astrocytes actively participate in brain tissue repair [1, 10]. As these cells function as a network then one would expect that their reparative reaction could influence basic characteristics of astrocyte population including their spatial arrangement.

In this study rotenone was used to induce a brain tissue insult and respective astroglial reaction. Rotenone is a naturally occurring botanical compound inhibiting NAD-linked substrate oxidation by mitochondria at the 
oxygen side of NADH dehydrogenase. This effect of rotenone is relatively specific for dopaminergic SNc neurons, what is presumably due to their large axonal arborization and respective energetic requirements. Higher vulnerability of these cells depends on their particular bioenergetic and morphological characteristics [11].

Our results show that rotenone leads to the significant increase in astrocyte numbers. The value of $\mathrm{AD}$ in $\mathrm{SNc}$ tissue of sham-operated animals provides evidence that this effect is not related to the mechanical injury of the tissue, linked to the procedure or influence of dimethyl sulphoxide. New astrocytes originate, most probably, from differentiated astrocytic cells located close to degenerating neurons. Mature astrocytes can re-enter the cell cycle and proliferate. Local proliferation of differentiated astrocytes is the main source of cells of this type in the cortex of postnatal brain [12].

We used RDF analysis to study spatial arrangement of nigral astrocytes. RDF describes how density of objects of interest varies as a function of distance from a reference object. The general algorithm involves determining how many objects are within a distance of $r$ and $r+\Delta r$ away from a given reference object. Such approach was applied earlier to analyze arrangement of intraand extracellular filaments [13], or gold-labelled calcium channels in plasma membrane [14]. RDF was used previously to study spatial clustering of excitatory synapses [15].

Our data indicate that nigral astrocytes are non-uniformly distributed in the SNc tissue. They appear to be more numerous in the proximity of neuronal cells. Rotenone-related degeneration of neurons stimulates the migration of astrocytes closer to cell bodies of the former. This effect is stronger 40 days after the infusion while decreasing later. The most likely explanation for the transitory nature of the effect is that some neurons degenerate, and 70 - 200 days after the infusion their remnants cannot be recognized reliably and used as reference objects. This fact may influence the results of RDF analysis.

It was shown that AD increase observed 40 days after the infusion parallels the increase in spatial clustering of astrocytes. Later, the level of astrocyte clustering becomes similar in the infused and control regions. This can be explained by the following putative scheme of events: the rotenone infusion causes astrocyte proliferation and respective increase in their numbers. During a particular period daughter astroglial cells stay close to parent ones. Later they move apart and astroglial cell clusters disperse.

\section{CONCLUSIONS}

The intracerebral $12 \mu \mathrm{g}$ rotenone infusion leads to degeneration of neurons in the infused region of the SNc tissue. Our data show that local population of nigral astrocytes reacts to this tissue impairment by growing in numbers and changing spatial arrangement of individual cells. RDF analysis gives evidence of transient clustering of astrocytes and their migration towards cell bodies of degenerating neurons. The revealed spatial features of nigral astrogliosis provide important details about cellular mechanisms underlying repair and adaptive plasticity of the brain tissue.

The authors of this study confirm that the research and publication of the results were not associated with any conflicts regarding commercial or financial relations, relations with organizations and/or individuals who may have been related to the study, and interrelations of coauthors of the article.

\section{А.О. Богданюк, О.Г. Ніконенко}

ПРОСТОРОВІ ХАРАКТЕРИСТИКИ АСТРОГЛІОЗУ У ЧОРНІЙ СУБСТАНЦІЇ ЗА УМОВ РОТЕНОНОВОЇ МОДЕЛІ ХВОРОБИ ПАРКІНСОНА

Вивчали просторові характеристики астрогліозу у зоні компактної частини чорної субстанції $(\mathrm{SNc})$ за умов ротенонової моделі хвороби Паркінсона. Дослідження було проведено на дорослих щурах-самцях лінії Вістар, які отримували внутрішньомозкову інфузію 12 мкг ротенону у 
ділянку лівої SNc. Тканину SNc аналізували через 40, 70 та 200 діб після інфузії. Було показано, що ротенон викликає підвищення щільності астроцитів у всіх проаналізованих часових точках, вказуючи, таким чином, на проліферацію цих клітин. Аналіз радіальної функції розподілу (RDF) показав, що просторовий розподіл астроцитів у тканині $\mathrm{SNc} \epsilon$ нерівномірним. Щільність цих клітин була більш високою поруч 3 клітинними тілами нейронів, особливо на боці інфузії. На додаток, RDF-аналіз дав змогу виявити просторові кластери астроцитів, які виникали через 40 діб після інфузії. Отримані результати вказують на те, що астрогліоз у чорній субстанції, який спостерігається у ротеноновій моделі хвороби Паркінсона, пов'язаний зі змінами у просторовому розподілі астроцитів. Такі зміни відображають перебудови у архітектурі тканини SNc, що виникають у відповідь на ротенонзалежну дегенерацію нейронів.

Ключові слова: астроцити; ротенон; тваринна модель; хвороба Паркінсона; просторовий розподіл.

Інститут фізіології ім. О.О.Богомольия, Національна академія наук України, Kиїв; e-mail: agn@biph.kiev.ua

\section{А.А. Богданюк, А.Г. Никоненко}

\section{ПРОСТРАНСТВЕННЫЕ ХАРАКТЕРИСТИКИ АСТРОГЛИОЗА В ЧЕРНОЙ СУБСТАНЦИИ В УСЛОВИЯХ РОТЕНОНОВОЙ МОДЕЛИ БОЛЕЗНИ ПАРКИНСОНА}

Исследовали пространственные аспекты астроглиоза в зоне компактной части черной субстанции (SNc) в условиях ротеноновой модели болезни Паркинсона. Исследование было проведено на взрослых крысах-самцах линии Вистар, которым осуществляли внутримозговую инфузию 12 мкг ротенона, в область левой $\mathrm{SNc}$. Ткань $\mathrm{SNc}$ анализировали через 40, 70 и 200 сут после инфузии. Было показано, что ротенон вызывает увеличение плотности астроцитов во всех проанализированных временных точках, указывая на пролиферацию этих клеток. Анализ радиальной функции распределения (RDF) показал, что астроциты неравномерно распределены в ткани SNc. Их плотность была выше рядом с клеточными телами нейронов, особенно на стороне инфузии. Кроме этого, RDF-aнализ позволил выявить присутствие пространственных кластеров астроцитов, возникающих через 40 сут после инфузии. Полученные результаты указывают на то, что астроглиоз в черной субстанции, который наблюдается в ротеноновой модели болезни Паркинсона, сопряжен с изменениями в пространственном распределении астроцитов. Такие изменения отражают перестройки архитектуры ткани SNc, которые возникают в ответ на ротенонзависимую дегенерацию нейронов.

Ключевые слова: астроциты; болезнь Паркинсона; животная модель; ротенон; пространственное распределение.

\section{REFERENCES}

1. Khakh BS, Sofroniew MV. Diversity of astrocyte functions and phenotypes in neural circuits. Nat Neurosci. 2015; 18(7):942-52.

2. Attwell D, Buchan AM, Charpak S, Lauritzen M, Macvicar BA, Newman EA. Glial and neuronal control of brain blood flow. Nature. 2010; 468 (7321): 232-43.

3. Barker AJ, Ullian EM. Astrocytes and synaptic plasticity. Neuroscientist. 2010; 16 (1): 40-50.

4. Stogsdill JA, Ramirez J, Liu D, Kim YH, Baldwin KT, Enustun E, Ejikeme T, Ji RR, Eroglu C. Astrocytic neuroligins control astrocyte morphogenesis and synaptogenesis. Nature. 2017; 551 (7679): 192-7.

5. Haydon PG, Carmignoto G. Astrocyte control of synaptic transmission and neurovascular coupling. Physiol Rev. 2006; 86 (3): 1009-31.

6. López-Hidalgo M, Hoover WB, Schummers J. Spatial organization of astrocytes in ferret visual cortex. J Comp Neurol. 2016; 524 (17): 3561-76.

7. Tsai HH, Li H, Fuentealba LC, Molofsky AV, TaveiraMarques R, Zhuang H, Tenney A, Murnen AT, Fancy SP, Merkle F, Kessaris N, Alvarez-Buylla A, Richardson WD, Rowitch DH. Regional astrocyte allocation regulates CNS synaptogenesis and repair. Science. 2012; 337 (6092): 358-62.

8. Voitenko LP, Nikonenko AG. [Modification of experimental rotenone model of Parkinson's disease]. Fiziol Zh. 2015; 61 (1): 83-90. [Ukrainian].

9. Barker AJ, Ullian EM. New roles for astrocytes in developing synaptic circuits. Commun Integr Biol. 2008; 1 (2): 207-11.

10. Burda JE, Bernstein AM, Sofroniew MV. Astrocyte roles in traumatic brain injury. Exp Neurol. 2016; 275 (Pt 3): 305-15.

11. Pacelli C, Giguere N, Bourque MJ, Levesque M, Slack RS, Trudeau LE. Elevated mitochondrial bioenergetics and axonal arborization size are key contributors to the vulnerability of dopamine neurons. Curr Biol. 2015; 25 (18): 2349-60.

12. Ge WP, Miyawaki A, Gage FH, Jan YN, Jan LY. Local generation of glia is a major astrocyte source in postnatal cortex. Nature. 2012; 484 (7394): 376-80.

13. Kumar S, Yin X, Trapp BD, Paulaitis ME, Hoh JH. Role of long-range repulsive forces in organizing axonal neurofilament distributions: evidence from mice deficient in myelin-associated glycoprotein. J Neurosci Res. 2002; 68 (6): 681-90.

14. Gathercole DV, Colling DJ, Skepper JN, Takagishi Y, Levi AJ, Severs NJ. Immunogold-labeled L-type calcium channels are clustered in the surface plasma membrane overlying junctional sarcoplasmic reticulum in guinea-pig myocytesimplications for excitation-contraction coupling in cardiac muscle. J Mol Cell Cardiol. 2000; 32 (11): 1981-94.

15. Nikonenko I, Nikonenko A, Mendez P, Michurina TV, Enikolopov G, Muller D. Nitric oxide mediates local activity-dependent excitatory synapse development. Proc Natl Acad Sci U S A. 2013; 110 (44): E4142-51.

Received 17.07.2018 